\title{
Hubungan Pengetahuan Dengan Tingkat Kesiapsiagaan Siswa/I SMA N 9 Takengon Terhadap Bencana Gempa Bumi di Kecamatan Ketol Kabupaten Aceh Tengah Tahun 2017
}

\section{Correlation between Knowledge and Preparedness Level of Students of SMA N 9 Takengon Against Earthquake Disaster in Ketol District, Central Aceh Regency in 2017}

\author{
Syahferi Anwar ${ }^{(1)^{*}}$ \& Rike Mahara(2) \\ Program Studi Ilmu Keperawatan, Universitas Haji Sumatera Utara, Indonesia
}

Disubmit: 13 Oktober 2020; Diproses: 14 Oktober 2020; Diaccept: 14 November 2020; Dipublish: 01 Desember 2020 *Corresponding author: E-mail: syahferia@gmail.com

\begin{abstract}
Abstrak
Gempa bumi yang berkekuatan 6,2 SR melanda Kabupaten Aceh Tengah pada juli 2013 lalu meluluh lantakkan hampir seluruh wilayah Kabupaten Aceh Tengah dan Kabupaten Bener Meriah. Kecamatan Ketol adalah wilayah terparah yang terkena dampak gempa tersebut. Tanah longsor, rumah ambruk hingga korban jiwa yang tidak sedikit. Setelah terjadinya musibah tersebut, pendidikan pelatihan dan simulasi menghadapi bencana belum pernah dilakukan, namun dalam fase rehabilitasi bencana tanggap darurat hal ntersebut perlu dilakukan. apabila suatu saat dampak bencana serupa dapat minimalisir bahkan di hindari. Penelitian ini mengunakan jenis Deskriptif Korelasi dengan pendekatan Cross Sectional. Jumlah populasi sebanyak 95 orang. Tekhnik pengambilan sampel menggunakan tekhnik Total Sampling sehingga jumlah sampel sebanyak 95 orang. Analisa data yang digunakan uji spearman's Rho. Hasil penelitian pengetahuan dengan tingkat kesiapsiagaan terhadap bencana gempa bumi diperoleh nilai $p=0,000$. Hal ini menunjukkan bahwa ada hubungan yang pengetahuan dengan tingkat kesiapsiagaan siswa/I SMA N 9 Takengon terhadap bencana gempa bumi di Kecamatan Ketol Kabupaten Aceh Tengah Tahun 2017. Sebagai Kesimpulan dan harapan peneliti kepada sekolah sekolah maupun pemerintah terkait untuk membentuk kegiatan kesiapsiagaan demi meningkatkan pengetahuan dan kesiapsiagaan dalam menghadapi bencana gempa bumi. Sehingga kesiapsiagaan dalam menghadapi bencana dapat lebih maksimal.
\end{abstract}

Kata Kunci: Pengetahuan; Tingkat Kesiapsiagaan; Bencana; Gempa Bumi

\begin{abstract}
An earthquake measuring 6.2 on the Richter scale struck Central Aceh Regency in July 2013 and then devastated almost the entire region of Central Aceh and Bener Meriah Regencies. Ketol Subdistrict is the worst affected area. Landslides, collapsed houses and many casualties. Post-disaster, educational training and disaster management simulations have never been carried out, but at the emergency response stage, rehabilitation is necessary. If one day the impact of a similar disaster can be minimized or even avoided. This research uses descriptive correlation type with cross sectional approach. Total population 95 people. The sampling technique used a total sampling technique so that the number of samples was 95 people. Data analysis used the Spearman's Rho test. The results of the knowledge research with the level of earthquake disaster preparedness obtained the value of $p=0.000$. This shows that there is a relationship between knowledge and the preparedness level of students at SMA N 9 Takengon for the earthquake disaster in Ketol District, Central Aceh Regency in 2017. As a conclusion and the hope of researchers to schools and the government concerned to establish preparedness activities to increase knowledge and preparedness in facing earthquakes. So that preparedness in the face of disasters can be maximized.
\end{abstract}

Keywords: Knowledge; Preparedness Level; Disaster; Earthquake

Rekomendasi mensitasi:

Anwar, S., \& Mahara, R., 2020. Hubungan Pengetahuan Dengan Tingkat Kesiapsiagaan Siswa/I SMA N 9 Takengon Terhadap Bencana Gempa Bumi di Kecamatan Ketol Kabupaten Aceh Tengah Tahun 2017. Jurnal Penelitian Pendidikan, Psikologi dan Kesehatan (I-P3K), 1(3): 19-200. 


\section{PENDAHULUAN}

Negara Kesatuan Republik Indonesia (NKRI) secara keseluruhan berada pada posisi rawan bencana, baik bencana geologis maupun bencana alam yang di akibatkan ulah manusia. Dengan posisi geografis yang unik, kepulauan Indonesia berada pada pertemuan tiga titik lempeng tektonik raksasa (Eurasia, india Australia dan pasifik) dan terletak diantara benua Australia dan samudera hindia dan pasifik yang terdiri dari +_ 17.000 pulau yang sebagian besar berhadapan dengan laut lepas dengan garis pantai lebih dari $81.000 \mathrm{~km}$. posisi geografis tersebut menyebabkan Indonesia rentan terhadap letusan gunung berapi dan gempa bumi, terpengaruh gelombang pasang hingga tsunami serta cuaca ekstreem yang berpotensi menimbulkanbanjir dan tanah longsor serta kekeringan. Berdasarkan sejarah keberencanaan yang terhimpun, hampir semua bencana alam di dunia telah terjadi di Indonesia dan setiap terjadi bencana alam, setiap kali itu pula kejadian tersebut menimbulkan korban jiwa (Hendrianto, 2012).

Namun kejadian awal tentang $b$ value gempa bumi di sumatera tahun 1964-2013 oleh madzalim pada tahun 2013 menyatakan kecenderungan kejadian gempa bumi semakin meningkat selama kin meningkat selama 49 tahun terakhir. Bahkan setelah gempa tahun 2004 peningkatan kejadian gempa bumi semakin tajam.

Seluruh provinsi aceh merupakan daerah yang rawan bencana gempa bumi. Disamping bencana itu wilayah aceh juga rawan terhadap bencana alam lain seperti, tanah lonsor, angin putting beliung, gunung meletus, kebakaran hutan, dan tsunami.

Kabupaten aceh tengah merupakan wilayah yang sangat berpotensi terjadinya bencana gempa bumi jika di lihat dari aspek geografis, iklim, geologis, faktor keragaman sosisal, budaya dan politik. Pada tahun 2013 lalu terjadi gempa bumi tektonik dengan criteria tinggi dengan kekuatan 6,2 skala richter di kedalaman $10 \mathrm{Km}$ yang berpusat di kecamatan ketol kabupaten aceh tengah. Dalam peristiwa tersebut menimbulkan korban meninggal sebanyak34 orang, dan jumlah luka ringan dan berat 450 orang.

Penanganan pasca gempa yang telah di lakukan pada daerah tersebut sesuai dengan amanat undang-undang dasar Nomor 24 Tahun 2007 tentang penanggulangan bencana, pemerintah daerah perlu mengupayakan untuk melaksanakan: perencanaan penanggulangan bencana, pengurangan faktor-faktor penyebab resiko bencana, penelitian, pendidikan dan pelatihan penanggulangan resiko bencana ke dalam sistem pendidikan formal dan informal dan penyelenggaraan penyuluhan dan pelatihan kepada masyarakat di daerah rawan bencana, serta mengalokasikan anggaran penanggulangan bencana, pencegahan, dan pengurangan resiko bencana (rencana aksi rehabilitasi dan rekonstruksi wilayah pasca bencana gempa bumi aceh tengah dan benar meriah tahun 2013/2014) (BNPB, 2010).

Namun berdasarkan pengamatan yang dilakukan oleh peneliti, ditemukan bahwa masyarakat dan pemerintah daerah belum melakukan penataandan pengelolaan bencana yang baik dan benar. Hal tersebut dapat dilihat dari struktur 
tahan gempa (rumah, tempat berlindung) yang masih berada di wilayah perbukitan. Hal tersebut diperparah dengan tidak ditemukannya sistem peringatan dini seperti peta evakuasi, sirine dan pendukung lainnya yang terpasang di daerah tersebut.

Hal tersebut sesuai dengan survey yang dilakukan oleh BNPB, BPS, dan UNFPA tentang pilot survey pengetahuan, sikap dan perilaku kesiapsiagaan menghadapi bencana pada tahun 2013 menunjukkan bahwa tingginya pengetahuan responden terhadap bencana gempa bumi tidak disertai dengan ketersediaan peralatan atau fasilitas kesiapsiagaan. Hampir separuh dari masyarakat mengetahui akan terjadinya bencana alam melalui pemberitahuan melalui radio dan televisi, mengaktifkan sirine peringatan tsunami, dan peringatan dini tentang gempa bumi (BNPB, 2013).

Sebagai akibatnya, manusia sering kurang peduli dan tidak melakukan langkah penanganan dan pencegahan terhadap berbagai kemungkinan yang akan terjadi. Faktor penunjang kegiatan pengelolaan bencana agar lebih efektif adalah dengan meningkatkan pengetahuan tentang bencana itu sendiri. baik itu dari segi jenis, cirri, dan tandatanda dari setiap bencana itu sendiri. Selain itu, harus didukung oleh system penunjang yang memadai. Mulai dari sosialisasi, pelatihan, peningktan informasi komunikasi sistem peringatan dini dan lain-lain (Soehatman, 2010).

Survey yang di lakukan pada siswa/i SMA N 9 Takengon pada tanggal 14 Januari 2017, di dapatkan keterangan dari siswa/i bahwa di sekolah tersebut belum dilakukan pendidikan tentang managemen bencana khususnya gempa bumi. Baik itu penyuluhan, simulasi, dan pendidikan bencana. Hal tersebut di dukung dengan pernyataan kepala sekolah dan wakil kepala sekolah bidang kemahasiswaan bahwa siswa/I mulai dari kelas X sampai kelas XII dengan jumlah siswa/I sebanyak 156 orang belum mendapatkan sosialisasi pengetahuan bencana baik itu dari pemerintah daerah melalui dinas pendidikan, BPBD, Dinas social, dan tenaga kesehatan di bidang terkait.

Pernyataan tersebut menunjukkan bahwa sosialisasi dan pendidikan pengetahuan kebencanaan pada daerah tersebut masih minim dilakukan. Namun demikian, wilayah SMA N 9 Takengon berada pada ruang lingkup daerah rawan bencana gempa bumi dan tanah longsor kabupaten aceh tengah jika di lihat dari peta indeks resiko pergerakan tanah BNPB Provinsi Aceh.

Pemilihan SMA N 9 Takengon sebagai target penelitian diharapkan dapat menjadi faktor penyebaran informasi yang efektif bagi masyarakat sekitarnya.

Oleh karena itu, peneliti tertarik untuk melakukan penelitian tentang Hubungan Pengetahuan Dengan Tingkat Kesiapsiagaan di SMA N 9 Takengon terhadap gempa bumi.

\section{METODE PENELITIAN}

Metode yang digunakan dalam penelitian ini adalah metode penelitian deskriptif dengan menggunakan studi Cross Sectional, yang bertujuan mengetahui hubungan tentang suatu keadaan objektif yang dilakukan dengan 
menggunakan kuisioner yang di bagikan kepada masing-masing responden. Dimana pengetahuan ini adalah untuk mengetahui hubungan pengetahuan dengan tingkat kesiapsiagaan SMA N 9 Takengon terhadap bencana gempa bumi di Kecamatan Ketol Kabupaten Aceh tengah Tahun 2017.

Selanjutnya penelitian ini juga di desain penelitian deskriptif korelasional yaitu: untuk mengetahui hubungan pengetahuan dengan tingkat kesiapsiagaan SMA N 9 Takengon terhadap bencana gempa bumi di Kecamatan Ketol Kabupaten Aceh Tengah tahun 2017. Variabel adalah objek penelitian atau yang menjadi titik perhatian suatu penelitian. Penelitian ini menggunakan dua variabel, yakni satu variabel bebas (variabel independen) atau variabel $\mathrm{X}$ dan satu Variabel terikat (Variabel Dependen) atau Variabel Y. Variabel bebas dalam penelitian ini adalah pengetahuan siswa/I, sedangkan Variabel terikat adalah Tingkat kesiapsiagaan Siswa/i.

Penelitian ini dilaksanakan di SMA N 9 Takengon Kecamatan Ketol Kabupaten Aceh Tengah, pemilihan lokasi ini dikarenakan lokasi ini adalah lokasi strategis untuk membahas masalah kebencanaan. Baik itu dari segi letak sekolah yang sangat sulit di jangkau, ditambah lagi dengan riwayat kejadian bencana gempa bumi yang berpusat di daerah tersebut pada tahun 2013 silam dan juga sangat dekat dengan salah satu gunung berapi aktif bernama gunung api Burni Telong yang berjarak sekitar $10 \mathrm{Km}$ dari titik lokasi sekolah. Hal ini menambah resiko bencana gempa bumi menjadi lebih tinggi pada lokasi yang di pilih.
Menurut Aris Santjaka (2011), Populasi adalah keseluruhan subjek dimana sebagian daripadanya akan di ambil untuk dilakukan pengukuran yang hasilnya akan dijadikan dasar untuk generalisasi. Populasi dalam penelitian ini adalah seluruh Siswa/i yang berada di Kelas X dan XI SMA N 9 Takengon Sebanyak 95 responden.

Responden tersebut terdiri dari 58 responden yang berada di kelas X dan 37 responden berada di kelas XI.

Sampel adalah sebagian dari jumlah dan karakteristik yang dimiliki oleh populasi tersebut (Sugiyono, 2010).

Menurut Aris Sandjaka (2011) sampel adalah bagian populasi yang di ambil dengan cara tertentu, dimana pengukuran dilakukan. Sampel dalam penelitian ini adalah siswa/i yang berada di Kelas X dan XI SMA N9 Takengon. Teknik pengambilan sampel dilakukan dengan sampling jenuh yaitu tekhnik penentuan sampel bila semua anggota populasi digunakan sebagai sampel dengan jumlah sampelnya sebanyak 95 Siswa/i. 
Tabel 1. Definisi Operasional

\begin{tabular}{|c|c|c|c|c|}
\hline Variabel & $\begin{array}{l}\text { Definisi } \\
\text { Operasio } \\
\text { nal }\end{array}$ & Alat Ukur & $\begin{array}{l}\text { Hasil } \\
\text { Ukur }\end{array}$ & $\begin{array}{l}\text { Sak } \\
\text { ala } \\
\text { Uku } \\
\text { r }\end{array}$ \\
\hline $\begin{array}{l}\text { Variabel } \\
\text { Independen } \\
: \\
\text { Pengetahau } \\
\mathrm{n} \quad \text { siswa/I } \\
\text { tentang } \\
\text { bencana } \\
\text { gempa bumi }\end{array}$ & $\begin{array}{l}\text { Hasil atau } \\
\text { pengetah } \\
\text { uan yang } \\
\text { dimiliki } \\
\text { siswa/I } \\
\text { tentang } \\
\text { bencana } \\
\text { gempa } \\
\text { bumi }\end{array}$ & $\begin{array}{l}\text { Kuisioner } \\
\text { sebanyak } \\
(12) \\
\text { pertanya } \\
\text { an } \\
\text { dengan } \\
\text { pilihan } \\
\text { Sangat } \\
\text { Benar :5 } \\
\text { Benar :4 } \\
\text { Cukup } \\
\text { benar :3 } \\
\text { Salah :2 } \\
\text { Sangat } \\
\text { salah:1 }\end{array}$ & $\begin{array}{l}\text { Baik = } \\
37-60 \\
\text { Cuku } \\
\text { p = } \\
25-36 \\
\text { Kuran } \\
g \quad= \\
12-24\end{array}$ & $\begin{array}{l}\text { ordi } \\
\text { nal }\end{array}$ \\
\hline $\begin{array}{l}\text { Variabel } \\
\text { Dependen: } \\
\text { Tingkat } \\
\text { kesiapsiaga } \\
\text { an bencana } \\
\text { gempa bumi }\end{array}$ & $\begin{array}{l}\text { Reasksi } \\
\text { atau } \\
\text { respon } \\
\text { siswa/i } \\
\text { yang } \\
\text { dilakukan } \\
\text { pada saat } \\
\text { terjadi } \\
\text { bencana }\end{array}$ & $\begin{array}{l}\text { Kuisioner } \\
\text { sebanyak } \\
(30) \\
\text { pertanya } \\
\text { an } \\
\text { dengan } \\
\text { pilihan: } \\
1 . \\
\text { Pernah:2 } \\
2 . \text { Tidak } \\
\text { Pernah : } \\
1\end{array}$ & $\begin{array}{l}\text { Sanga } \\
\mathrm{t} \text { siap } \\
=51- \\
60 \\
\text { Siap = } \\
41-50 \\
\text { Belu } \\
\mathrm{m} \\
\text { siap = } \\
30-40\end{array}$ & $\begin{array}{l}\text { Ordi } \\
\text { nal }\end{array}$ \\
\hline
\end{tabular}

\section{HASIL DAN PEMBAHANSAN}

Penelitian ini dilaksanakan pada Siswa/I kelas X dan XI di Sekolah Menengah Atas Negeri 9 Takengon Kecamatan Ketol Kabupaten Aceh tengah dengan jumlah 95 siswa/i.

Lokasi penelitian ini bertempat di Kecamatan Ketol Kabupaten Aceh Tengah yang berada pada ketinggian 1200 MDPL yang menempatkan tempat ini sebagai salah satu dataran tinggi di Indonesia. Lokasi penelitian sekolah mengenah atas negeri 9 takengon berada pada sekitran daerah perbukitan. Hal ini menyebabkan tempat penelitian termasuk daerah yang rawan bencana gempa bumi dan tanah longsor. Pada tanggal 2 juli 2013 lalu, daerah tersebut mengalami musibah gempa bumi dengan kekuatan 6,2 SR dan gempa susulan berkekuatan 4,3, 5,5, dan
5,2 SR yang menyebabkan 39 orang meninggal dan 420 orang mengalami cidera.

Berdasarkan latar belakang yang telah di uraikan pada bab sebelumnya, peneliti tertarik untuk melakukan penelian tentang hubungan pengetahuan dengan tingkat kesiapsiagaan siswa/I Sekolah Menengah Atas Negeri 9 Takengon terhadap gempa bumi di kecamatan ketol. Penelitian telah dilaksanakan pada Sabtu, 12 Agustus 2017 dengan metode pengambilan data melalui lembar kuisioner yang telah di sediakan oleh peneliti. Hasil penelitianakan di jelaskan lebih lanjut dengan hasil di bawah ini.

Berdasarkan penelitian yang telah di lakukan mengenai hubungan pengetahuan dengan tingkat kesiapsiagaan siswa/I terhadap gempa bumi di Sekolah Menengah Atas Negeri 9 Takengon Kecamatan Ketol Kabupaten Aceh Tengah, didapatkan karakteristik responden penelitian yang dapat di lihat dalam data demografi responden sebagai berikut :

Tabel 2. Distribusi Frekwensi Demografi Siswa/I Sekolah Menengah Atas Negeri 9 Takengon

\begin{tabular}{lll}
\hline $\begin{array}{l}\text { Data } \\
\text { Demografi }\end{array}$ & Frekwensi & $\begin{array}{l}\text { Persentase } \\
\%\end{array}$ \\
\hline Jenis Kelamin & & \\
Laki-Laki & 56 & 58.9 \\
Perempuan & 39 & 41.1 \\
\hline Total & 95 & 100 \\
\hline
\end{tabular}

Berdasarkan data yang di peroleh data dari tabel di atas, menunjukkan mayoritas laki-laki sebagai sampel penelitian dengan jumlah 56 responden (58.9\%). 
Tabel 3. Distribusi Frekwensi Pengetahuan Tentang Gempa Bumi

\begin{tabular}{llll}
\hline No & Pengetahuan & $\begin{array}{l}\text { Frekwe } \\
\text { nsi }\end{array}$ & $\begin{array}{l}\text { Persentasi } \\
\%\end{array}$ \\
\hline 1 & Baik & 31 & 32.6 \\
2 & Cukup & 53 & 55,8 \\
3 & Kurang & 11 & 11.6 \\
\hline & Jumlah & 95 & 100.0 \\
\hline
\end{tabular}

Berdasarkan table 3, didapatkan hasil Pengetahuan terhadap gempa bumi di Sekolah Menengah Atas Negeri 9 Takengon mayoritas pada kategori Cukup sebanyak $53(55,8 \%)$ responden.

Tabel 4. Distribusi Frekwensi Kesiapsiagaan Terhadap Gempa Bumi

\begin{tabular}{llll}
\hline No & Pengetahuan & Frekwensi & $\begin{array}{l}\text { Persen } \\
\text { tasi\% }\end{array}$ \\
\hline 1 & Sangat Siap & 11 & 11.6 \\
2 & Siap & 74 & 77.9 \\
3 & Belum Siap & 11 & 10.5 \\
\hline & Jumlah & 95 & 100.0 \\
\hline
\end{tabular}

Berdasarkan dari hasil table distribusi frekwensi tingkat kesiapsiagaan terhadap gempa bumi di atas menunjukkan mayoritas tingkat kesiapsiagaan siswa/I berada pada kategori Siap sebanyak 74 (77.9\%) responden.

Tabel 5. Tabulasi Silang Hubungan Pengetahuan dengan Tingkat Kesiapsiagaan Siswa/I Sekolah Menengah Atas Negeri 9 Takengon

\begin{tabular}{lllllll}
\hline & & $\begin{array}{l}\text { Kesiapsiagaan } \\
\text { Belum } \\
\text { siap }\end{array}$ & Siap & $\begin{array}{l}\text { Sangat } \\
\text { Siap }\end{array}$ & $\begin{array}{l}\text { Tot } \\
\text { al }\end{array}$ & P \\
\hline Penget & Kurang & 11 & 0 & 0 & 11 & \\
ahuan & Cukup & 0 & 53 & 0 & 53 & 0,000 \\
& Baik & 0 & 21 & 10 & 31 & \\
\hline Total & & 11 & 74 & 10 & 95 & \\
\hline
\end{tabular}

Berdasarkan tabel di atas dapat diketahui dari 95 responden dengan kategori pengetahuan kurang dengan kesiapsiagaan belum siap sebanyak 11 orang. Pengetahuan dengan kategori cukup dengan kesiapsiagaan siap 53 orang. Pengetahuan dengan kategori baik dengan kesiapsiagaan siap 21 orang, dan kesiapsiagaan sangat siap 10 orang.

Analisa data mengenai hubungan pengetahuan dengan tingkat kesiapsiagaan dalam penelitian ini menggunakan uji korelasi Spearman Rho dan didapatkan hasil $P=0.000$. maka ditarik kesimpulan bahwa ada hubungan yang signifikan antara pengetahuan dengan tingkat kesiapsiagaan siswa/I Sekolah Menengah Atas Negeri 9 Takengon Terhadap Bencana gempa Bumi di Kecamatan Ketol Kabupaten Aceh Tengah pada tahun 2017.

Berdasarkan hasil penelitian ini diketahui pengetahuan berperan penting dalam meningkatkan kesiapsiagaan terhadap bencana gempa bumi. Berdasarkan penelitian yang telah di lakukan di dapatkan hasil mayoritas pengetahuan siswa/I berada pada kategori cukup atau sebanyak 55 responden $(57,9 \%)$.

Pengetahuan yang cukup berdasarkan mayoritas pengetahuan tentang pernyataan kegiatan mengantisipasi bencana, tindakan gempa bumi saat berkendara, peralatan pertolongan pertama yang perlu di sediakan di sekolah, peralatan penerangan serta alat komunikasi yang di gunakan pada saat terjadi bencana.

Pengetahuan siswa tentang kegiatan mengantisipasi bencana tidak didapatkan melalui pembelajaran khusus dan formal. Melainkan didapatkan melalui pengalaman menghadapi bencana yang sebelumnya terjadi. Sama halnya dengan tindakan menghadapi gempa bumi pada 
saat berkendara. Namun, lain halnya dengan peralatan pertolongan pertama yang perlu di persiapkan di sekolah. Peralatan P3K, peta jalur evakuasi, sirine, penyediaan sumber informasi, dan juga peralatan pendukung lainnya.

Namun peneliti tidak menyertakan pertanyaan yang membahas tentang ketersediaan peralatan kesiapsiagaan yang di butuhkan pada suatu sekolah. Tapi tidak menutup kemungkinan pengetahuan tentang peralatan pertolongan pertama didapatkan siswa/I dari sumber yang peneliti tidak ketahui baik itu media informasi elektronik maupun surat kabar. Sumber informasi yang di sebutkan peneliti di atas sesuai dengan pengetahuan siswa tentang alat penerangan dan komunikasi yang di perlukan pada saat terjadi bencana. Hampir seluruh siswa/I memiliki pengetahuan tentang media informasi dan komunikasi tersebut.

Dari pembahasan pengetahuan di atas, peneliti menyimpulkan bahwa siswa/I memiliki pengetahuan tentang bagaimana cara mengantisipasi bencana, apa tindakan yang di lakukan, peralatan yang di perlukan untuk pertolongan pertama, dan peralatan serta informasi yang bersumber dari pengalaman pribadi maupun informasi yang bukan berasal dari kegiatan-kegiatan resmi seperti pelatihan dan lain-lain. Hal tersebut sesuai dengan pernyataan yang di sampaikan oleh siswa/I dan juga kepala sekolah SMA $\mathrm{N} 9$ Takengon yang menyatakan belum pernah di lakukan atau diberikan pendidikan tentang bencana pada sekolah tersebut.

Hasil penelitian yang menyebutkan pengetahuan dalam kategori cukup sejalan dengan hasil penelitian yang di lakukan Syafrizal (2013) tentang Tingkat Pengetahuan, Kesiapsiagaan Dan Partisipasi Masyarakat Dalam Pembangunan Jalur Evakuasi Tsunami Di Kota Padang dengan hasil pengetahuan masyarakat tinggi atau dengan persentase $81 \%$.

Dari kedua hasil penelitian di atas sesuai dengan pendapat Mubarak (2011) yang menyebutkan bahwa bahwa lokasi tempat tinggal, pendidikan, pengalaman dan umur respon dan mempengaruhi hasil pengetahuan yang di ukur.

Pengetahuan yang cukup dapat diartikan bahwa sebagian besar siswa/i sudah memiliki pengetahuan yang cukup tentang bencana gempa bumi. Namun pengetahuan belum cukup sebagai modal menghadapi bencana gempa bumi tanpa di sertai dengan kesiapsiagaan dan fasilitas kesiapsiagaan.

$$
\text { Selanjutnya hasil penelitian }
$$
menunjukkan mayoritas responden memiliki tingkat kesiapsiagaan kategori siap dengan jumlah 74 responden $(77,9 \%)$. Tingkat kesiapsiagaan kategori siap berdasarkan mayoritas pertanyaan jawaban responden pada kuisioner yang membahas tentang definisi bencana, penyebab bencana, prediksi terjadi bencana, riwayat bencana, tanda-tanda tsunami, persiapan menghadapi bencana, bencana yang pernah di alami responden, dukumen yang perlu di selamatkan pada saat bencana, informasi jika situasi sudah aman.

Dalam menghadapi sebuah bencana sering kali kita lalai dan bahkan pasrah menunggu kapan bencana itu terjadi. Padahal dalam menghadapi bencana kita harus mempersiapkan segala sesuatunya untuk menghadapi setiap bencana yang 
akan datang untuk mengurangi segala resiko yang di timbulkan pada setiap bencana. Kesiapsiagaan menghadapi bencana adalah kegiatan yang berfokus bagaimana menangani dan mempersiapkan diri untuk menghadapi bencana mulai dari mengetahui apa itu bencana, apa cirinya, dan bagaimana cara menghadapinya untuk meminimalisir setiap resiko yang di timbulkan. Definisi bencana, penyebab bencana, persiapan untuk menghadapinya, dan informasi adalah hal yang sangat dasar untuk mempersiapkan diri dalam menghadapi bencana. Dari pembahasan di atas, siswa/i telah mengetahui apa itu gempa, apa cirinya dan bagai mana cara menghadaipinya, berdasarkan data yang di dapatkan, siswa/i telah mampu membedakan antara bencana gempa bumi dan tsunami dan siswa/i juga telah menyadari dalam kondisi bencana tindakan apa yang perlu di lakukan seperti menyelamatkan diri, menyelamatkan dokumen penting dan lainnya.

Hal ini didasari berdasarkan pengalaman yang pernah di alami responden yang menyebutkan bahwa responden pernah mengalami atau terlibat dalam suatu bencana gempa bumi. Selain itu, kegiatan lisan seperti berkunjung kelokasi gempa dan tsunami dapat memberikan dampak yang positif terhadap meningkatkan pengetahuan dan kesiapsiagaan dalam menghadapi bencana. Dikarenakan setiap lokasi yang memiliki riwayat bencana dapat menjadi alternative pendidikan informal.

Hasil penelitian yang menyebutkan mayoritas responden memiliki tingkat kesiapsiagaan pada kategori siap dengan jumlah 74 responden (77,9\%). Hasil penelitian Ini didukung oleh penelitian Ardin Widonartyas (2013) yang menjelaskan bahwa tingkat kesiapsiagaan terhadap bencana gempa bumi masyarakat Kecamatan Wedi dalam kategori siap, dengan diperoleh nilai persentase $70,9 \%$.

Menurut Soehatman Ramli (2010), pada tingkat pengembangan dan pemeliharaan kesiapsiagaan, berbagai usaha perlu di lakukan untuk menggandakan elemen penting seperti kemampuan koordinasi, fasilitas dan system operasional, peralatan dan persediaan kebutuhan dasar, pelatihan, kesadaran masyarakan dan pendidikan, informasi, dan kemampuan untuk menerima beban yang mengikat dalam situasi darurat.

Selanjutnya berdasarkan hasil uji statistik menggunakan uji korelasi Spearman Rho dengan taraf signifikasi $\alpha=$ 0.05 dengan $P$ Value 0,000 didapatkan Hasil penelitian bahwa ditemukan hubungan yang signifikan antara pengetahuan dengan tingkat kesiapsiagaan siswa/i SMA N 9 Takengon terhadap bencana gempa bumi di Kecamatan Ketol Kabupaten Aceh Tengah.

Hasil tersebut sesuai dengan pernyataan Ardin Widonartyas (2013) dalam penelitiannya menyatakan ada hubungan yang positif dan signifikan dari pengetahuan, sikap mobilisasi, dengan kesiapsiagaan dalam menghadapi bencana gempa bumi dengan nilai koefesien korelasi pengetahuan dengan kesiapsiagaan menghadapi gempa bumi $\mathrm{p}=0.001$.

Pengetahuan merupakan hasil mengingat akan suatu hal, termasuk mengingat kembali kejadian yang pernah 
di alami baik secara sengaja maupun tidak disengaja dan ini tidak terjadi setelah orang melakukan kontak atau pengamatan terhadap suatu objek tertentu melalui penginderaaan

Berdasarkan hasil penelitian yang di lakukan pada SMA N 9 Takengon mendapatkan hasil pengetahuan bencana yang cukup, namun hal ini kunjung terbalik dengan pernyataan siswa/i maupun pihak sekolah yang mengatakan belum pernah menerima pelatihan maupun pengarahan tentang bencana pada mereka. Namun pengetahuan tersebut bisa saja di dapatkaan oleh siswa/I dari sumber informasi lain seperti pengalaman, pendidikan lisan.

Kajian MPBI dan UNESCO yang melakukan penelitian di Nias Selatan mengatakan bahwa pengetahuan tentang gempa tidak hanya didapatkan dari bangku sekolah, namun juga berdasarkan pengalaman, media masa dan juga lingkungan. Pengetahuan dipengaruhi oleh beberapa faktor yang di antaranya ialah pendidikan, pekerjaan, umur, minat, pengalaman, kebudayaan lingkungan tempat tinggal, dan informasi yang di dapatkan.

Bencana adalah peristiwa atau rangkaian peristiwa yang megancam dan mengganggu kehidupan manusia yang di sebabkan oleh faktor alam maupun non alam atau kesengajaan manusia sehingga mengakibatkan timbulnya korban jiwa, kerusakan, kerugian harta benda, dan dampak psikologis. Menurut BNPB (2010) bencana dibagi menjadi 13 point yang salah satu di antaranya yang sering terjadi adalah gempa bumi.

Penganganan, penganggulangan dan pencegahan terus menerus di upayakan untuk meningkatkan kesiapsiagaan masyarakat dalam menghadapi bencana. Mulai dari peraturan perundangundangan, pendirian badan Negara yang mengatasi khusus masalah bencana sampai dengan pelatihan yang meliputi simulasi dilakuan demi untuk meningkatkan pengetahuan serta kesiapsiagaan untuk mengurangi resiko yang di timbulkan pada saat bencana terjadi.

Sekolah sebagai pemegang kebijakan dan keputusan tampaknya belum terbuka terhadap masalah-masalah kesiapsiagaan bencana khususnya bencana gempa bumi. Hal tersebut terlihat dari hasil jawaban pada saat dilakukan survey awal. Pihak sekolah mengatakan bahwa sekolah belum pernah menerima atau melakukan pelatihan atau pengenalan bencana kepada murid di sekolah tersebut. Namun, permasalahan tersebut tidak sepenuhnya berada pada pihak sekolah. BPBD selaku pemegang kendali sekaligus pengawasan langsung bidang bencana juga memiliki peranan sangat penting dalam melakukan upaya-upaya kesiapsiagaan dalam menghadapi bencana yang khususnya pada lingkup kerjanya.

Dalam hal sistem peringatan jika bencana gempa terjadi, kesiapsiagaan untuk akses mendapatkan informasi, akses untuk menyebarluaskan berita bencana, persiapan atau langkah, sampai penyiapan kelompok khusus yang berkaitan dengan kesiapsiagaan juga belum tampak pada sekolah tersebut.

Perawat sendiri memiliki pegaruh besar meningkatkan pengetahuan dan kesiapsiagaan masyarakat dalam menghadapi bencana. Ada 3 peranan penting yang di miliki perawat dalam 
bencana. Meliputi fase pre-impact atau kegiatan pra bencana, fase impact atau saat bencana, dan fase post impact setelah terjadi bencana (Efendi \& Makhfud, 2009).

Semua kegiatan tersebut dapat di jalankan apabila pengetahuan tentang bencana dan di terapkan dengan baik, pengetahuan tersebut akan meningkatkan kesiapsiagaan terhadap suatu bencana yang akan di hadapi.

Berdasarkan hasil uji statistik dan pembahasan di atas, dapat di simpulkan bahwa pengetahuan yang cukup mempengaruhi tingkat kesiapsiagaan siswa/i dalam hal ini pada kategori Siap, sehingga dapat di pastikan siswa/i SMAN 9 Takengon Siap dalam menghadapi bencana gempa bumi.

\section{SIMPULAN}

Berdasarkan penelitian yang dilakukan di Sekolah Menengah Atas Negeri 9 Takengon Kecamatan Ketol Kabupaten Aceh Tengah tentang hubungan pengetahuan dengan tingat kesiapsiagaan siswa/i terhadap bencana gempa bumi di dapatkan kesimpulan sebagai berikut:

1. Mayoritas pengetahuan terhadap bencana gempa bumi siswa/i di SMAN 9 Takengon memiliki pengetahuan pada kategori cukup

2. Mayoritas tingkat kesiapsiagaan menghadapi bencana gempa bumi siswa/i SMAN 9 Takengon berada pada kategori siap

3. Ada hubungan yang signifikan antara pengetahuan dengan tingkat kesiapsiagaan terhadap bencana gempa bumi di SMAN 9 Takengon Kecamatan Ketol Kabupaten Aceh
Tengah tahun 2017 dengan nilai signifikan $P=0.000$.

\section{DAFTAR PUSTAKA}

Aceh, A. R. (2016). Pengaruh Metode Focus Group Discussion Terhadap Kesiapsiagaan Bencana Gempa Bumi di SMK Negeri 1 Alo'oa Kota Gunung Sitoli. Medan: STIKes Rumah Sakit Haji Medan.

BNPB. (2013). Pilot Survey Pengetahuan, Sikap dan Perilaku Kesiapsiagaan Menghadapi Bencana Kota Padang. Badan Nasional Penanggulangan Bencana.

BNPB. (2010). Rencana Nasional Penanggulangan Bencana 2010-2014. Jakarta: Badan Nasional Penanggulangan Bencana.

Efendi, F., \& Makhfud. (2009). Keperawatan Kesehatan Komunitas Teori dan Praktik Dalam Keperawatan. Jakarta: Salemba Medika.

Hendrianto. (2012). Pemanfaatan Media Tradisional dalam Membangun Kesiapsiagaan Masyarakat Menghadapi Bencana. Dipetik Maret 2, 2012, dari http://madina.co.id/index.php/opini/4721pemanfaatan-media-tradisional-dalammembangun-kesiapsiagaan-masyarakatmenghadapi-bencana.html

Insan, K. G. (2011). Manajemen Bencana Pada Kegiatan Prabencana (Studi Kasus di Desa Kemiri Kecamatan Pati Kabupaten Jember). Jember: Ps IKM Universitas Jember.

Kesehatan, M. (2001). Keputusan Menteri Kesehatan RI Nomor 1357/Menkes/SK/XII/2001. Standar Minimal Penanggulangan Masalah Kesehatan Akibat Bencana dan Penanganan Pengungsi .

Mubarak, W. (2011). Promosi Kesehatan Masyarakat untuk Kebidanan. Jakarta: Salemba Medika.

Nurasalam. (2013). Metode Penelitian Ilmu Keperawatan. Jakarta: Salemba Medika.

Santjaka, A. (2011). Statistik Untuk Penelitian Kesehatan. Yogyakarta: Nuha Medika.

Setiadi. (2013). Konsep dan Praktik Penulisan Riset Keperawatan. Yogyakarta: Graha Ilmu.

Situmorang, L. L. (2015). Analisis Kesiapsiagaan Dinas Kesehatan Terhadap Penanggulangan 
Bencana di Kota Medan. Medan: Ps IKM USU.

Soehatman, R. (2010). Pedoman Praktis Manajemen Bencana. Jakarta: Dian Rakyat.

Sugiyono. (2010). Metode Penelitian Pendidikan Pendekatan Kuantitatif, Kualitatif dan RED. Bandung: Alfabeta.

Syafrizal. (2013). Tingkat Pengetahuan Kesiapsiagaan dan Partisipasi Masyarakat dalam Pembangunan Jalur Evakuasi Tsunami di Kota Padang. Padang: FIS Universitas Negeri Padang.

Wawan, \& A, D. (2011). Teori dan Pengukuran, Sikap dan Perilaku Masyarakat. Yogyakarta: Muha Medika.

WHO-WPR. (2003). Emergency Response Manual. Guidelines WHO Representatives And Country Offices In The Western Pacific Region .

Widonartyas, A. (2013). Kesiapsiagaan Masyarakat Dalam Menghadapi Bencana Gempabumi di Kecamatan Wdi Kabupaten Klaten. Surakarta: Universitas Muhammadiyah Surakarta. 